\title{
Producing Pragmatic Literature in the Third Mexican Provincial Council (1585)
}

\author{
Osvaldo R. Moutin
}

On 20 January 1585, the Third Mexican Provincial Council held its opening session. ${ }^{1}$ Exactly nine months later, the council promulgated a corpus of decrees ${ }^{2}$ and approved the statutes of the cathedral chapter, ${ }^{3}$ three catechisms, ${ }^{4}$ a directory for confessors and penitents, ${ }^{5}$ a list of court fees, and a ritual for administering the sacraments. In addition, the bishops of the Third Mexican Provincial Council sent a long letter to the king and a shorter one to Sixtus v, who had recently been promoted to the Apostolic See, asking for the expeditious approval and recognition of the decrees and the other documents.

Apart from the decrees and statutes of the cathedral chapter, most of the other documents have been considered "pastoral works", and seen as practical, as opposed to legal, productions. In this article, I will examine the authority and value that the bishops claimed for these "pastoral" documents. Considering that, according to canon law, one of the goals of a provincial council was to legislate, ${ }^{6}$ I will try to answer the question of why the Third Mexican Provincial Council not only produced decrees, but also other documents. Firstly, I will

1 The main sources of the Third Mexican Council have been edited by Carrillo Cázares, Manuscritos del Concilio Tercero Provincial Mexicano (1585), vols. 1-4.

2 A critical edition of the decrees can be found in Martínez Ferrer, Decretos del Concilio Tercero Provincial Mexicano 1585, 2 vols.

3 About the Statutes of Cathedral Chapters in the Third Mexican Provincial Council, see Terráneo, "El llamado 'III Concilio Provincial Mexicano' y los 'Estatutos' de la Santa Iglesia de México' o 'Reglas consuetas de la catedral de México' "; Vidal Gil, Los Estatutos del Cabildo de la catedral de México elaborados en el Tercer Concilio Provincial Mexicano (1585).

4 The catechisms were edited in Durán, "La transmisión de la fe"; Durán, "Los instrumentos americanos de pastoral (siglo XVI)".

5 The directory was published only recently: Carrillo Cázares, Manuscritos del Concilio Tercero Provincial Mexicano (1585), vol. 5; Durán, Monumenta catechética hispanoamericana, vol. 3.

6 Although Murphy (1947) focuses on the First Code of Canon Law (1917), his book is instructive, not least because of its sources to Chapter IV: Objects and Methods of Legislation, 5372. See Murphy, Legislative Powers of the Provincial Council.

(C) OSVALDO R. MOUTIN, 2020 | DOI:10.1163/9789004425736_009

This is an open access chapter distributed under the terms of the CC-BY-NC 4.olicernse. R. Moutin - 9789004425736 Downloaded from Brill.com04/26/2023 03:17:30PM 
focus on what a provincial council was, considering its canonical status and its attributions according to the canon law then in force. Here I will use a treatise written by the Franciscan friar Felice Peretti, addressed to the young and recently appointed archbishop of Milan, Charles Borromeo. Fray Peretti would become Pope Sixtus V in 1585, and, in 1589 was to approve the Third Mexican Provincial Council. Secondly, I will examine the "conciliar products" in order to explain their general purpose and why they were considered canonical documents. Finally, I will present some examples of the ways in which different matters were tackled in order to try to understand the normative value they had.

\section{$2 \quad$ What Was a Provincial Council in the Early Modern Period?}

Why did the Roman Catholic Church meet in the form of general, provincial councils or diocesan synods to legislate? Unlike in a modern state, there was, and still is, no separation of powers, nor were there any mechanisms for government control apart from its hierarchical structure, with the Roman Pontiff at its head. An initial answer can be found not in law but in theology if we turn our attention to the report or treatise written in 1565 by the Franciscan friar Felice Peretti for Charles Borromeo, entitled "De Concilio Provinciale". This report had been requested in order explain how to celebrate a provincial council according to classical canon law and according to the reform implemented by the Council of Trent, which had been promulgated less than two years before. It is a doctrinal work in which old and new legislation is organised with a particular aim: to explain how a provincial council should be celebrated de iure canonico. ${ }^{8}$ As was pointed out by the last sentences of the treatise, it had been written in such a way so that the required information could be accessed quickly in order to help the new Milanese bishop celebrate the provincial councils that he intended to, and indeed did celebrate. ${ }^{9}$

Fray Peretti summed up everything that was necessary to know to celebrate a provincial council in twenty chapters. For the purposes of this contribution, I will focus on four of them: the second and the third chapters, which

7 Sala, "Del Concilio Provinciale".

8 A study of the treatise can be found in Grohe, "Der Traktat De concilio provinciali (1565) des Felice Peretti (Sixtus V.)".

9 "Haec sunt, lllustrissime et Reverendissime Domine mihi Colen. ${ }^{\text {mo }}$ quae pro tuo jussu cursim, et in mei longi itineris properatione, scribere potui de Concilio Provinciali, quod tua lllustrissima Dnatio, Domino concedente, celebrare anhelat", in Sala, "Del Concilio Provinciale", 41. 
determined what a provincial council was, ${ }^{10}$ and the fifteenth and sixteenth chapters, which singled out the topics for which a provincial council had competence. ${ }^{11}$

So, what was the canonical significance of the provincial council? Fray Peretti wrote that both theologians and canon lawyers knew that there were three types of council: general, provincial, and episcopal. Regarding provincial councils, he explained that these were convoked by the metropolitan bishop who celebrated them with his suffragan bishops for the interests of the ecclesiastical province. He presented three reasons to explain the origins of councils: firstly, in the natural order, when human beings met with their progeny in order to settle any debated doctrine; secondly, drawing on the history of pagan Rome, when meetings were held to reach a decision through deliberation; and finally, because the Church had the promise of Christ that the assistance of the Holy Spirit would be given when two or more gathered in his name (Matthew 18), and so too did the Apostles. He based his arguments for general councils on Acts 15, for provincial councils on Acts 20, and for episcopal gatherings on Acts $21{ }^{12}$ To sum up, Peretti argued for the necessity of church councils for three reasons: the natural order, the experience of human history, and, finally and decisively, the positive divine law. This interpretation of the Holy Bible, especially in the last case, is not supported by present biblical exegesis. According to modern studies, what has been called the Council of Jerusalem celebrated between the years 49 and 50 and recorded by Luke in Acts 15 - had never taken place as such but had been the sum of several meetings. ${ }^{13}$ However, from the perspective of "Wirkungsgeschichte", the original sense intended by the author or even the events narrated with historical accuracy, were no longer relevant for the interpretation of a text. On the contrary, according to the "Wirkungsgeschichte", what mattered was the impact the text alone had in history. It is through the subject of the read text and the context in which it was read, that it gained its significance. ${ }^{14}$ Therefore, Peretti saw the praxis of the

\footnotetext{
10 Sala, "Del Concilio Provinciale", 33-34.

11 Sala, "Del Concilio Provinciale", 38-39.

12 Sala, "Del Concilio Provinciale", 34.

13 Rivas, "Algunas cuestiones historiográficas en torno al libro de los Hechos de los Apóstoles".

14 Gadamer, Truth and Method, 302: "In the sphere of historical understanding, too, we speak of horizons, especially when referring to the claim of historical consciousness to see the past in its own terms, not in terms of our contemporary criteria and prejudices but within its own historical horizon. The task of historical understanding also involves acquiring an appropriate historical horizon from which the traditionary text speaks, we will misunderstand the significance of what it has to say to us. To that extent this seems a legitimate hermeneutical requirement: we must place ourselves in the other situation
} 
primitive church as a rule which had been followed in the practice of medieval and early modern theology and canon law, and as a model of the usage of and need for councils, leaving to ecclesiastical law those norms through which the Church could change and adapt its practice.

Once it had been established that the celebration of councils - general, provincial, or episcopal - were a necessity as well as a resource of divine law, natural law and positive law, Peretti used chapters fifteen and sixteen to determine the competence of a provincial council. When considering for which topics a provincial council had no competence, he stated that everything that related to the definition of the faith was beyond a provincial council's authority. ${ }^{15}$ Without getting immersed too deeply in this conclusion, let me list the topics that according to Peretti's chapter 16 were to be treated by a provincial council: Provision for the vacancies of churches, absolution of irregularities, promoting the preaching of the Word of God; that beneficial Churches, as well as exempted ones, monasteries, hospitals, and colleges were to be visited; that churches were strengthened and that the unity of the churches was promoted; that examiners were appointed; that monastic cloisters were regulated; that nuns' monasteries were visited; that religious orders were guarded; that irregular cohabitations were abandoned; that bishops could present cases for trial; that the practice of duels was suppressed; that episcopal seminars were fostered; that laymen gave accounts regarding the administration of pious goods; that residency was observed; what should be established for those who entered sacred ministries; that clandestine marriages were nullified; what was to be observed in marriages, as well as in the mass and the other sacraments, according to the decrees of the Council of Trent; that complaints were heard by those who had been offended; that wicked incidents were investigated; that the lives and sermons of clerics were examined; that notorious crimes were corrected; that approved persons could denounce abuses in the dioceses; that the morality of the laity, especially of those members who induced others to sin, was overseen, as well as those who lurked around churches, including topics such as the adornment of women and similar matters; finally, that the Provincial

in order to understand it. We may wonder, however, whether this phrase is adequate to describe the understanding that is required of us. The same is true of a conservation that we have with someone simply in other to get to know him - i.e., to discover where he is coming from and his horizon. This not a true conversation, that is, we are not seeking agreement on some subject - because the specific contents of the conversation are only a means to get to know the horizon of the other person [...] Historical consciousness is clearly doing something similar when it transposes itself into the situation of the past and thereby claims to have acquired the right horizon".

Sala, "Del Concilio Provinciale", 38. 
Council should deal with everything that seemed convenient for the ecclesiastical province. ${ }^{16}$

Most of these cases were reinforced by a quotation from the reform canons of sessions 22 to 25 of the Council of Trent, and it is easy to see that these subjects were very broad and provided provincial councils with a wide scope of potential action. Regarding what we could call literary types or juridical forms, Peretti just used the expression "to issue decrees" with no further indication of what other types of "conciliar products" could be issued, but, returning to the list, one can easily see that not everything could be solved by issuing decrees as the following example will demonstrate.

\section{3 \\ Decrees and Other Products of the Third Mexican Provincial Council}

Let us now travel through time and space to Mexico in 1585. Almost fifteen clerics, including seven bishops and a group of theologians and canon lawyers, worked to produce several documents that touched practically every topic on Peretti's list. No source indicates that they knew Peretti's treatise, or any other similar one, but this should not come as a surprise. Most of these clerics had graduated from the best universities of their time - Salamanca, Alcalá de Henares or Granada - and the quality of their education had promoted them to the most important offices in the New World and the Old.

I shall not address the history of this provincial council, ${ }^{17}$ but rather briefly introduce those "conciliar products", that is, those documents that were promulgated, before discussing what we know about their genesis. For this purpose, I will examine the manuscripts of the Third Mexican Council, in which a great deal of information is included about the work achieved in the conciliar room.

The conciliar decrees were the most important documents of the council, even simply in terms of their widespread influence and application. First published in $1622,{ }^{18}$ they amounted to almost six hundred paragraphs divided into five books, touching on a wide variety of topics. ${ }^{19}$ The importance and

16 Sala, "Del Concilio Provinciale", 39.

17 Although a comprehensive history of the Third Mexican Provincial Council of 1585 still has not been published, several topics have been investigated. See Poole, Pedro Moya de Contreras, esp. chapters VIII-XI, 201-312.

18 Sanctum prouinciale concilium Mexici.

19 On the drafting of the decrees, see Galindo Bustos, Estudio del Aparato de Fuentes del Concilio Tercero Provincial de México (1585); Terráneo, La recepción de la tradición 
influence of this text is evident because it was quoted and referenced in the registers of episcopal visitations, in treatises and in the legislation and conciliar products of other ecclesiastical provinces of the New World. ${ }^{20}$ The statutes of the Cathedral of Mexico were also published in the same volume as the decrees, and these served as a model for all the cathedral churches in the ecclesiastical province. ${ }^{21}$

Along with the conciliar decrees, the council also issued a directory for confessors and penitents. As the title suggests, this work was to provide guidance to ministers and the general public regarding the practice of the sacrament of penance, but it remained unpublished until the first decade of the twenty-first century. ${ }^{22}$ This text has been studied extensively by Luis Martínez Ferrer, who identified the Jesuit Juan de la Plaza as its author. ${ }^{23}$ It is divided into two major parts: what priests should know in order to pass the examination for a license to hear confession, and a list of moral difficulties arranged according to different types of people, distinguished by their status, job, or duties.

Turning to what the historiography has tended to refer to as "pastoral works", we find three catechisms: a major one, a minor one for rustic and old people, and a third one about how to prepare the soul when death was imminent. ${ }^{24}$ A table of fees for ecclesiastical courts was also promulgated but never published. ${ }^{25}$ Completing the list of "pastoral works", a ritual was also drafted, but no single copy, manuscript or published, has survived, and we dispose of only a few recommendations and decisions from which to surmise its content.

Apart from the decrees and the "pastoral works", the provincial council wrote two letters. The first one was addressed to King Philip II and included three long memoriales, or reports, asking the king to resolve some important

conciliar limense en los decretos del III Concilio Provincial Mexicano; Moutin, Legislar en la América hispánica en la temprana edad moderna.

20 Cobo Betancourt and Cobo, La legislación de la arquidiócesis de Santafé en el periodo colonial.

21 Terráneo, "El llamado 'III Concilio Provincial Mexicano' y los 'Estatutos' de la Santa Iglesia de México' o 'Reglas consuetas de la catedral de México' "; Vidal Gil, Los Estatutos del Cabildo de la catedral de México elaborados en el Tercer Concilio Provincial Mexicano (1585).

22 Carrillo Cázares, Manuscritos del Concilio Tercero Provincial Mexicano (1585), vol. 5; Durán, Monumenta catechética hispanoamericana, vol. 3.

23 Martínez Ferrer, Directorio para confesores y penitentes.

24 The text of these catechisms: Durán, "Los instrumentos americanos de pastoral (siglo XVI)"; Durán, "La transmisión de la fe"; Carrillo Cázares, Manuscritos del Concilio Tercero Provincial Mexicano (1585), vol. 1, 475-548.

25 Carrillo Cázares, Manuscritos del Concilio Tercero Provincial Mexicano (1585), vol. 3, $237-256$. 
issues. ${ }^{26}$ After concluding the council, on 28 October 1585 the bishops sent a second letter to the recently appointed Pope Sixtus V, previously known as Felice Peretti, the Franciscan Friar who had written the treatise about the holding of provincial councils. ${ }^{27}$ In 1589 , Sixtus v issued three documents granting recognition or papal approval of the Third Mexican Provincial Council. ${ }^{28}$

\section{4 \\ Pragmatic Literature as a Legal Instrument for Evangelisation}

That being said, if canon law ordered the issuing of decrees, why did the bishops of the Third Mexican Provincial Council need other documents?

Five days after the opening of the council, the bishops asked the theological consultants to draft a catechism for indios, Africans, and Spaniards, so that they could be instructed in a standardized way. In that logic, this would end the diversity, which experience had taught them was a cause of many obstacles to obedience. ${ }^{29}$ From this it can be inferred that there was no lack of catechisms, but that the bishops aimed at a consistent uniformity with regard to the content of faith for old and new Christians alike. In the decrees, the bishops determined that these catechisms, which contained a summary of what Christians were obliged to believe and how this was to be explained, were to be the only ones used for religious instruction, and that every bishop should be in charge of approving the translations to different indigenous languages.

Pedro de Feria, one of the bishops who could not take part in the council, sent a report in which he asked that learned friars and clerics who were experienced in the pastoral care of indigenous people, should write short treatises about the most important contents of faith. He suggested several topics and

26 Carrillo Cázares, Manuscritos del Concilio Tercero Provincial Mexicano (1585), vol. 2, 69$108 ; 112-156$.

27 Carrillo Cázares, Manuscritos del Concilio Tercero Provincial Mexicano (1585), vol. 2, 109-112.

28 Breve Romanum Pontificem given in 28 October 1589, in: Metzler, America Pontificia. Primi saeculi evangelizationis 1493-1592, vol. 2, 1398-1400. Sixtus v also ruled that all provincial councils had to receive their recognitio from the Sacred Congregation of the Council, see Gómez-Iglesias, "La bula «Immensa Aeterni Dei» de Sixto V (22-1-1588)". On the case of the Third Mexican Provincial Council, see Fornés Azcoyti, El proceso de la aprobación romana del III Concilio de México, 1585-1589. On the royal approval, see Martínez Ferrer, "Un "pequeño" conflicto entre Madrid y Roma". For the general political and ecclesiastical context of the reformation of the Church, see García Hernán, "La curia romana, Felipe II y Sixto V".

29 Carrillo Cázares, Manuscritos del Concilio Tercero Provincial Mexicano (1585), vol. 1, $116-118$. 
recommended that each one should be treated by a different author. However, it is his last recommendation that is the most noteworthy: He proposed that all these treatises were compiled in one single volume written in Spanish. This work should guide priests in Indian parishes and prevent them from using the Latin language and authorities when preaching to Indians - a common practice he had heard from some preachers. ${ }^{30}$

Dionisio de Rivera Flores, prosecutor of the council, also asked for a ritual book to be approved by the provincial council. He explained that both regular and secular priests used several manuscripts to teach the doctrine and to perform liturgical ceremonies, which went against the canons of the Council of Trent. ${ }^{31} \mathrm{He}$ was not the only one to comment on this situation. Ortiz de Hinojosa, a theological consultant, also wanted prayers to be collected into a single volume, including the ones for priests, along with the psalms, and instructions for administering the sacraments. ${ }^{32}$

So far, I have spoken about the need for the catechism and the ritual, but I will now focus on the other major "pastoral work of the council". The directory for confessors and penitents was even longer than the decrees, and it aimed at providing confessors with sufficient doctrinal knowledge and professional instruction for the exercise of their office, especially for those particular and difficult cases that occurred in the archbishopric and province. All parish priests had to own a copy and follow it, guiding themselves by using its doctrine and erudition. ${ }^{33}$

The directory covered fewer topics than the decrees, referring only to moral and penal questions, and it was drafted by the Jesuit Juan de la Plaza, who had also written the catechisms. However, it was not an entirely new work and the influence of Martin de Azpilcueta's manual, among others, can be perceived easily. According to the decrees, anyone who had an office with cura animarum, regardless of whether he was a secular or a regular confessor, had to possess copies of it, one in Spanish and another one in "Mexican". It was to be used not only for the immediate practice of the sacrament of penance but also for the preparation and examination of candidates for the priesthood. As

30 Carrillo Cázares, Manuscritos del Concilio Tercero Provincial Mexicano (1585), vol. 1, 295-297.

31 Carrillo Cázares, Manuscritos del Concilio Tercero Provincial Mexicano (1585), vol. 1, 149-152.

32 Carrillo Cázares, Manuscritos del Concilio Tercero Provincial Mexicano (1585), vol. 1, 391.

33 Lib. III, tit. II De Officio rectoris, et plebani, De vigilantia, et cura circa subditos, praesertim in sacramentorum receptione, § 15, in Sanctum prouinciale concilium Mexici, 48-49; lib. v, tit. XII De Poenitentiis et remisionibus, § 8, in Sanctum prouinciale concilium Mexici, 97-98. 
we said above, it consisted of two major parts: one to prepare candidates for the priesthood, and the other one included a catalogue of several offices and the moral risks that they potentially entailed. The directory has been called the first professional ethics book in America. ${ }^{34}$

However, following the spirit of the conciliar decree, the directory was not meant to be an obstacle to erudition by virtue of being a summary. On the contrary, by gathering material from various famous and respected sources, it offered the necessary instruction because it was a guide for learning and for taking the exam to obtain the license for hearing confession. A few examples will help to shed light on this statement.

When the bishops were reviewing the provincial council of Seville of $1512,{ }^{35}$ they ruled that a decree should be drafted to establish what could and what could not be done during a cessatio a divinis, a measure closely related to an interdict, which prohibited a priest or a community from celebrating certain sacraments and ceremonies. ${ }^{36}$ They wanted to copy exactly what Bartolomé de Medina had written in his instruction for confessors, so a decree was drafted and the disposition was included in the directory. ${ }^{37}$ Unlike Medina's work, however, in the directory it was arranged in a question and answer format, which firstly explained the difference between an interdict and a cessatio a divinis, then established who could impose it, and, finally, set the penalty for clerics who broke this decree. ${ }^{38}$

This brief example serves to illustrate the practical character of the directory. Those with a superior education in theology or canon law might not have needed this information, but, if necessary, they would have known where to look for it. The directory did not replace erudite knowledge but rather organised it in a systematic way so that it could be easier acquired and applied. Although the Pontifical and Royal University of Mexico had existed for almost thirty years, many of the candidates were thousands of kilometres away or unable to attend university, and so the directory was considered as a vehicle of instruction for these candidates.

34 See also Poole, "El Directorio para confesores del III Concilio Mexicano (1585)"; Luque Alcaide, "Ética y teología ante el Nuevo Mundo".

35 Carrillo Cázares, Manuscritos del Concilio Tercero Provincial Mexicano (1585), vol. 1, $77^{0}-771$.

36 Lib. V, tit. XI De sententia excomunicationis, $\S 7$, in Sanctum prouinciale concilium Mexici, 96 .

37 Medina, Breve instruction de como se ha de administrar el Sacrame[n]to de la penitencia, $\S 14$.

38 Carrillo Cázares, Manuscritos del Concilio Tercero Provincial Mexicano (1585), vol. 5, 144-146. 
Something similar happened with regard to the decree on usury. The physician Pedro López had warned the council that several contracts were being used in the commerce of silver and other goods between merchants in Mexico and Spain. ${ }^{39}$ The council asked him for a more detailed account of these contracts. ${ }^{40}$ Twenty-four cases were submitted to the theological and juridical consultants of the council who responded by outlining the morality of every single one of them. ${ }^{41} \mathrm{~A}$ long decree on usury was drafted, which described and provided solutions to two of these cases. ${ }^{42}$ Regarding the remaining cases, the decree stated that the confessor should first consult the directory, where many other cases were explained, and follow those rules in order to condemn or acquit a suspect. If further doubts appeared, they were to consult theologians and jurists in such difficult cases. ${ }^{43}$

\section{$5 \quad$ Concluding Remarks}

We have explained that a provincial council was an exercise of the spiritual and jurisdictional potestas of the episcopacy, which derived its authority from natural law, positive law, and, above all, from divine positive law promulgated by Christ and being in accordance with the continuous practice of the Church. The main goal of a provincial council was to legislate, and therefore the decrees were its major outcome. Nevertheless, through them, other instruments could become legitimate texts that acquired normative value, as was the case of the catechism or the directory for confessors. If we return to the list made by Pope Sixtus v when he was still Fray Felice Peretti, it becomes clear that most of these topics were addressed by the decrees and by the other documents.

39 Carrillo Cázares, Manuscritos del Concilio Tercero Provincial Mexicano (1585), vol. 1, 418-420.

40 Carrillo Cázares, Manuscritos del Concilio Tercero Provincial Mexicano (1585), vol. 1, 431-432.

41 Carrillo Cázares, Manuscritos del Concilio Tercero Provincial Mexicano (1585), vol. 1, 497-535.

42 Lib. v, tit. XI De usuriis, in Sanctum prouinciale concilium Mexici, 88-89. About the draft of this decree, see Cummins, "Imperial Policy and Church Income"; Martínez López-Cano, "La usura a la luz de los concilios provinciales mexicanos e instrumentos de pastoral"; Martínez López-Cano, "La Iglesia novohispana ante la usura y las prácticas mercantiles en el siglo XVI"; Martínez López-Cano, "Socialización y religiosidad del médico Pedro López (1527-1597)"; Staples, "Tentaciones de oro y plata”; Moutin, Legislar en la América hispánica en la temprana edad moderna, 128-130.

Lib. v, tit. XI De usuriis, § 6, in Sanctum prouinciale concilium Mexici, 89. 
As has been shown, these documents could be the work of individuals, and herein lies the particularity of provincial councils, especially in the New World: apart from the canons produced, they included other normative documents. Nowadays, these historical sources are often classified as "pastoral works", but this - to our mind - is an anachronistic term, which reflects a more recent view that detaches these texts from their juridical origin. As a matter of fact, in the 16th century they were canonical documents arranged for a practical use.

In conclusion, the normative value of these "pastoral works" can only be understood in relation to their conciliar origin. They have been labelled in such an anachronistic manner only because other similar works already existed. In fact, many texts of that type circulated in manuscript and printed copies, but not all of them were considered good, orthodox or appropriate. They created an undesirable diversity, as pragmatic literature of this kind could prove to be dangerous, harmful or simply ineffective. Furthermore, they could result in a waste of resources and effort in places where a lack of personnel and economic provision played a major role. If these "conciliar pastoral works" were useful, it was because they were written by experts at the request of the proper authorities and because they were promulgated by a provincial council. After all, they had "the authority and approval of this council". ${ }^{4}$

\section{Acknowledgements}

The author would like to thank Chistiane Birr for the comments and Natalie Cobo for the revision of the text.

\section{Bibliography}

\section{Printed Sources}

Carrillo Cázares, Alberto, Manuscritos del Concilio Tercero Provincial Mexicano (1585). Edición, estudio introductorio, notas, versión paleográfica y traducción de textos latinos, 5 vols., Zamora, México 2006-2011.

Cobo Betancourt, Juan Fernando and Natalie Cobo, La legislación de la arquidiócesis de Santafé en el periodo colonial, Bogotá 2018. 
Durán, Juan Guillermo, Monumenta catechética hispanoamericana, vol. 3: (Siglos XVIXVIII), Buenos Aires 2017.

Martínez Ferrer, Luis, Decretos del Concilio Tercero Provincial Mexicano 1585. Edición histórico crítica y estudio preliminar por Luis Martínez Ferrer, 2 vols., Zamora 2009.

Medina, Bartolomé de, Breve instruction de como se ha de administrar el Sacrame[n]to de la penitencia: dividida en dos libros compuesta por el padre maestro fray Bartholome de Medina [...]; En la qual se contiene todo lo que ha de saber, y hazer el sabio confessor para curar almas, y todo lo que deue hazer el penite[n]te para conseguir el fructo de tan admirable medicina, Huesca 1581: Impressa con licẽcia, en casa de Ioan Perez de Valdiuielso.

Metzler, Josef, America Pontificia, vol. 2: Primi saeculi evangelizationis 1493-1592. Documenta Pontificia ex registris et minutis praesertim in Archivo Secreto Vaticano existentibus, Città del Vaticano 1991.

Sala, Aristide, "Del Concilio Provinciale. Trattatello di Frà Felice da Monte Alto, poi Sisto V", in Sala, Aristide (ed.), Documenti circa la vita e le gesta di san Carlo Borromeo, vol. 1, Milano 1857, 33-41.

Sanctum prouinciale concilium Mexici celebratum anno dni millessmo quingentessmo octuagessimo quinto, Mexici 1622: apud Ioannem Ruiz, Excudebatq[ue].

\section{Literature}

Cummins, Victoria Hennessey, "Imperial Policy and Church Income: The Sixteenth Century Mexican Church”, in The Americas 43:1 (1986), 87-103.

Durán, Juan Guillermo, "Los instrumentos americanos de pastoral (siglo XVI)", in Saranyana, Josep Ignasi, Primitivo Tineo, Antón M. Pazos, Miguel Lluch-Baixauli and María Pilar Ferrer (eds.), Evangelización y teología en América (siglo XVI): X Simposio Internacional de Teología de la Universidad de Navarra, vol. 2, Pamplona 1990, 747-792.

Durán, Juan Guillermo, "La transmisión de la fe. Misión apostólica, catequesis y catecismos en el Nuevo Mundo (siglo XVI)", in Imbert, Escudero (ed.), Historia de la Evangelización de América. Trayectoria, identidad y esperanza de un continente. Actas del simposio internacional, Ciudad del Vaticano 1992, 285-352.

Fornés Azcoyti, Ignacio, El proceso de la aprobación romana del III Concilio de México, 1585-1589, Roma 2005 .

Gadamer, Hans-Georg, Truth and Method, London 2004.

Galindo Bustos, Jesús, Estudio del Aparato de Fuentes del Concilio Tercero Provincial de México (1585), México 2010.

García Hernán, Enrique, "La curia romana, Felipe II y Sixto V", in Hispania Sacra 46, no. 94 (1994), 631-649.

Gómez-Iglesias, Valentín, "La bula «Immensa Aeterni Dei» de Sixto V (22-1-1588): la revisión de los decretos de los concilios provinciales”, in L'Année canonique. Hors série (1992), 409-415. 
Grohe, Johannes, "Der Traktat De concilio provinciali (1565) des Felice Peretti (Sixtus V.)", in Annuarium Historiae Conciliorum 42 (2010), 403-412.

Luque Alcaide, Elisa, "Vida urbana en México (siglo XVI)", in Facultad de Teología San Vicente Ferrer (ed.), Ética y teología ante el Nuevo Mundo: Valencia y América. Actas del VII Simposio de Teología Histórica (28-3o abril 1992), Valencia 1993, 193-212.

Martínez Ferrer, Luis, Directorio para confesores y penitentes. La Pastoral de la Penitencia en el Tercer Concilio Mexicano (1585), Pamplona 1996.

Martínez Ferrer, Luis, “Un 'pequeño’ conflicto entre Madrid y Roma. La polémica sobre la inclusión de la jurisdicción civil en el proemio de los Decretos de los terceros concilios de Lima (1582/83) y México (1585)", in Dalla-Corte Caballero, Gabriela, Ricardo Piqueras Céspedes and Meritxell Tous Mata (eds.), América: Poder, conflicto y política, Murcia 2013, 1-15.

Martínez López-Cano, María del Pilar, "La usura a la luz de los concilios provinciales mexicanos e instrumentos de pastoral", in Cervantes Bello, Francisco Javier and María del Pilar Martínez López-Cano (eds.), Los concilios provinciales en Nueva España. Reflexiones e influencias, México 2005, 285-314.

Martínez López-Cano, María del Pilar, "La Iglesia novohispana ante la usura y las prácticas mercantiles en el siglo XVI: entre el discurso y la práctica”, in Cervantes Bello, Francisco Javier, Alicia Tecuanhuey Sandoval and María del Pilar Martínez LópezCano (eds.), Poder civily catolicismo en México, siglos XVI al XIX, Puebla, México D.F. 2008, 75-102.

Martínez López-Cano, María del Pilar, "Pedro López de Medina y la moral mercantil de su tiempo", in Rodríguez-Sala, María Luisa and Luis Martínez Ferrer (eds.), Socialización y religiosidad del médico Pedro López (1527-1597): de Dueñas (Castilla)a la ciudad de México, México 2013, 217-247.

Moutin, Osvando Rodolfo, Legislar en la América hispánica en la temprana edad moderna. Procesos y características de la producción de los Decretos del Tercer Concilio Provincial Mexicano (1585), Frankfurt am Main 2016.

Murphy, Francis Joseph, Legislative Powers of the Provincial Council. A Historical Synopsis and a Commentary, Washington, D.C. 1947.

Poole, Stafford, "El Directorio para confesores del III Concilio Mexicano (1585): Luz en vida religiosa y social novohispana del siglo XVI", in Mayer, Alicia and Ernesto de la Torre Villar (eds.), Religión, podery autoridad en la Nueva España, México 2004, 111-124.

Poole, Stafford, Pedro Moya de Contreras. Reforma católica y poder real en la Nueva España, 1571-1591, trans. Alberto Carrillo Cázares, 2nd ed., México 2012.

Rivas, Luis Heriberto, "Algunas cuestiones historiográficas en torno al libro de los Hechos de los Apóstoles", in Teología 68 (1996), 221-236.

Staples, Anne, "Tentaciones de oro y plata", in Lira Gonzalez, Andres, Alberto Carrillo Cazares and Claudia Ferreira Ascencio (eds.), Derecho, política y sociedad en Nueva España a la luz del Tercer Concilio Provincial Mexicano (1585), México 2013, 371-384. 
Terráneo, Sebastián, La recepción de la tradición conciliar limense en los decretos del III Concilio Provincial Mexicano, Buenos Aires 2010.

Terráneo, Sebastián, “El llamado 'III Concilio Provincial Mexicano’ y los ‘Estatutos’ de la Santa Iglesia de México' o 'Reglas consuetas de la catedral de México' ", in Revista de Estudios Histórico-Jurídicos 33 (2011), 613-637.

Vidal Gil, Jesús, Los Estatutos del Cabildo de la catedral de México elaborados en el Tercer Concilio Provincial Mexicano (1585), Roma 2014. 